\title{
Influence of birth weight and gender on lipid status and adipose tissue gene expression in lambs
}

\author{
Jacqueline M Wallace, John S Milne, Raymond P Aitken and Clare L Adam
}

Rowett Institute of Nutrition and Health, University of Aberdeen, Bucksburn, Aberdeen AB21 9SB, UK

Correspondence should be addressed to J M Wallace Email Jacqueline.Wallace@ abdn.ac.uk

\begin{abstract}
Intrauterine growth restriction (IUGR) is a risk factor for obesity, particularly when offspring are born into an unrestricted nutritional environment. In this study, we investigated the impact of IUGR and gender on circulating lipids and on expression of adipogenic, lipogenic and adipokine genes in perirenal adipose tissue. Singleton lambs born to overnourished adolescent dams were normal birth weight (N) or IUGR (32\% lower birth weight due to placental insufficiency). IUGR lambs exhibited increased fractional growth rates but remained smaller than $\mathrm{N}$ lambs at necropsy (d77). At 48 days, fasting plasma triglycerides, non-esterified fatty acids and glycerol were elevated predominantly in IUGR males. Body fat content was independent of prenatal growth but higher in females than in males. In perirenal fat, relative to male lambs, females had larger adipocytes; higher lipoprotein lipase, fatty acid synthase and leptin and lower IGF1, IGF2, IGF1R, IGF2R and hormonesensitive lipase mRNA expression levels, and all were independent of prenatal growth category; peroxisome proliferator-activated receptor gamma and glycerol-3-phosphate dehydrogenase (G3PDH) mRNA expression were not affected by IUGR or gender. Adiposity indices were inversely related to G3PDH mRNA expression, and for the population as a whole the expression of IGF system genes in perirenal fat was negatively correlated with plasma leptin, fat mass and adipocyte size, and positively correlated with circulating IGF1 levels. Higher plasma lipid levels in IUGR males may predict later adverse metabolic health and obesity, but in early postnatal life gender has the dominant influence on adipose tissue gene expression, reflecting the already established sexual dimorphism in body composition.
\end{abstract}

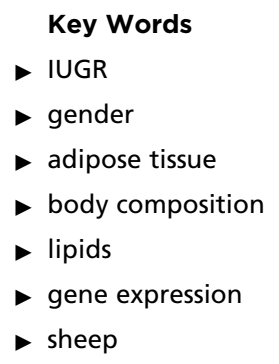

Journal of Molecular Endocrinology (2014) 53, 131-144

\section{Introduction}

Inadequate prenatal growth velocity leading to intrauterine growth restriction (IUGR), premature delivery and low birth weight is a risk factor for adverse metabolic health and obesity, particularly when the newborn is exposed to a calorie-rich environment, and thereby has the potential to exhibit rapid compensatory growth. Exemplars of this scenario exist in a number of human and animal studies, with endpoints measured at various life stages (Hokken-Koelega et al. 1995, Ong et al. 2000, Parsons et al. 2001, Louey et al. 2005, De Blasio et al. 2007, Wallace et al. 2011). The prevalence of obesity in adult life varies with age, ethnicity, education level and indices of economic deprivation (http://www.noo.org.uk/ NOO_about_obesity/inequalities, 4th March 2014), but

Published by Bioscientifica Ltd 
nonetheless in 2008 it was estimated globally that $14 \%$ of women compared with $10 \%$ of men aged more than 20 years were obese (http://apps.who.int/bmi/index.jsp, 4th March 2014). This sex difference in the incidence of obesity is evident in childhood and diverges further at puberty (girls fatter than boys; McCarthy et al. 2006, Nightingale et al. 2013), suggesting that gender is likely to be an equally important consideration, as well as prenatal growth status in the establishment of an obese phenotype. Indeed, a recent review of sex differences in developmental programming models has revealed widespread interactions between prenatal environmental challenges, including manipulation of maternal and/or foetal nutrition and gender on offspring outcomes (Aiken \& Ozanne 2013). Alterations in the genes regulating adipose tissue proliferation, differentiation, metabolism and signalling are likely to be integral to the development of an obese phenotype, while circulating lipid biomarkers may be an early presage of later metabolic health. Thus our aim herein was to examine the impact of poor prenatal growth followed by unlimited postnatal nutrition on plasma lipid status and adipose tissue gene expression in both male and female offspring. The sheep was our precocial species of choice because adipogenesis and lipogenesis begin before birth, as in the human, and singleton birth weight is similar after a relatively long gestation (Ojha \& Budge 2012).

Evidence from inducible gene knockouts and from preadipocyte and stem cell culture studies supports a role for locally produced insulin-like growth factors (IGF1 and IGF2) in adipocyte proliferation and differentiation (Holly et al. 2006, Kleiman et al. 2013). IGF1 also plays a role in the modulation of energy balance in that its administration to hypophysectomised rats and to growth hormone (GH)-deficient humans reduces adipose tissue leptin expression and peripheral leptin concentrations respectively (Böni-Schnetzler et al. 1996, Bianda et al. 1997). Growth factors, including IGF1, also induce transcription factors such as peroxisome-proliferator-activated receptor gamma (PPARG; Scavo et al. 2004), which in turn plays a central role in adipocyte differentiation and the co-ordination of a number of adipose tissue-specific genes involved in lipid deposition and metabolism (Semple et al. 2006). These include lipogenic genes such as lipoprotein lipase $(L P L)$, which enhances fatty acid uptake into adipocytes, fatty acid synthase (FASN), which catalyses fatty acid synthesis, and glycerol-3-phosphate dehydrogenase $(G 3 P D H)$, which is involved in glyceroneogenesis, and lipolytic genes such as hormone-sensitive lipase $(H S L)$, which is involved in the hydrolysis of stored triglycerides to release non-esterified fatty acids (NEFAs).

As earlier studies using sheep models indicate that varying maternal nutrition influences foetal adipose tissue expression of some of the above regulatory genes (Bispham et al. 2003, Muhlhausler et al. 2007, Long et al. 2012), in this study we chose to use a model where the dams received equivalent nutrition during both pregnancy and lactation and where variation was further constrained by the use of single embryo transfers. To this end, we used an adolescent sheep model of utero-placental insufficiency, in which overnourishing dams throughout gestation results in $\sim 50 \%$ of lambs born being defined as markedly IUGR, whereas the remaining lambs are either not growth perturbed or only mildly growth perturbed (Wallace et al. 2004, 2010). Thus comparison of these IUGR lambs and normal birth weight lambs all born to ewes receiving a high nutrient intake during pregnancy allows us to examine their phenotype without the confounding effect of differences in maternal nutrition. We have recently reported data on the growth of these offspring pre-weaning (Wallace et al. 2014). IUGR lambs were $>30 \%$ lighter at birth and subsequently showed increased fractional growth for the eight parameters of body size, but still remained smaller at necropsy (11 weeks). IUGR and gender were associated with altered glucose handling at 7 weeks of age, and gender was the dominant influence on peripheral metabolic hormone concentrations throughout the early postnatal period and on body size and composition at necropsy. We now investigate the hypothesis that contrasting prenatal and early postnatal growth trajectories influence plasma lipid biomarkers and adipose gene expression in a genderspecific manner and relate the findings to differences in adiposity.

\section{Materials and methods}

\section{Animals}

All procedures were licensed under the UK Animals (Scientific Procedures) Act 1986 and approved by Local Ethical Review Committee. The derivation of the lambs is described in detail by Wallace et al. (2014). Briefly, growing adolescent recipient ewes (Dorset Horn $\times$ Mule) had been implanted with singleton embryos, derived from superovulated donors (Border Leicester $\times$ Scottish Blackface) and a single sire (Dorset Horn), and given a high quality complete diet ad libitum throughout pregnancy and lactation. The complete diet contained $12 \mathrm{MJ}$

Published by Bioscientifica Ltd. 
metabolisable energy and $140 \mathrm{~g}$ crude protein/kg dry matter, and ad libitum intakes were calculated to promote rapid maternal growth during pregnancy leading to impaired placental growth, and hence restricted foetal growth in $\sim 50 \%$ of cases, followed by maximal milk yields during the 11-week lactation. Lambs had access to their mothers' feed throughout and remained gonad intact. There was a continuous distribution of birth weights, and individuals were classified as prenatally growth restricted (IUGR) if birth weight was $<4000 \mathrm{~g}$. This was equivalent to two s.D.s below the mean birth weight of normally grown fetuses of control-intake adolescent ewes of identical age and genotype studied previously (Wallace et al. 2004, 2010). This study involved full data on 17 IUGR lambs (eight males and nine females) and 21 normal birth weight lambs (N; 12 males and nine females), with the original embryo donors represented equally in both prenatal growth categories. Lambs were weighed at 5-day intervals until necropsy at 11 weeks of age.

\section{Plasma analyses}

At $48.5 \pm 0.3$ days of age, a temporary jugular catheter was inserted in order to obtain fasting blood samples: the lambs were prevented from suckling by blocking access to the udder using an udder cover, any residual food remaining in the mother's hopper was removed, and blood samples were collected $3 \mathrm{~h}$ later at $0,+10$ and $+20 \mathrm{~min}$. These three blood samples, together with a further three non-fasted samples collected mid-morning at 5-day intervals during the final 10 days of the study, were analysed to determine plasma triglyceride, NEFA, glycerol and cholesterol concentrations. This was achieved using an automated clinical analyser (KONE) using kits supplied by the manufacturer (Labmedics, Manchester, UK), and variation between duplicates was $<5 \%$ in all cases. The samples collected during the final 10 days of the study were also analysed by RIA for leptin, IGF1 and insulin (Bruce et al. 1991, MacRae et al. 1991, Marie et al. 2001) and a mean concentration during this period calculated. This provided a summary measure of the hormonal milieu in the days leading up to adipose tissue collection.

\section{Adipose tissue sampling}

Lambs were killed by lethal injection of sodium pentobarbitone (10-15 ml Euthesate; $200 \mathrm{mg}$ pentobarbitone/ ml; Willows Francis Veterinary, Crawley, UK) at $77.5 \pm$ 0.4 days of age. Selected organs including the perirenal fat depot were weighed. Perirenal fat was sampled in duplicate and either snap frozen in isopentane chilled by liquid nitrogen and stored at $-80^{\circ} \mathrm{C}$ until gene expression analysis or fixed in $10 \%$ neutral buffered formalin and embedded in paraffin for subsequent quantification of adipocyte size and number. The lamb body was divided into carcass and non-carcass components, and the fat and protein content of the carcass component were determined after removing the head and feet as described earlier (Wallace et al. 2006).

\section{Quantitative real-time RT-PCR}

mRNA levels for ten genes putatively involved in adipocyte development and function in lamb perirenal fat tissue were measured by quantitative real-time RT-PCR using techniques described previously (Matsuzaki et al. 2006). Probe and primer sets for sheep-specific sequences of genes are detailed in Supplementary Table 1, see section on supplementary data given at the end of this article and were designed using Primer Express Software, version 3.0.1 (Applied Biosystems) with 5-carboxyfluorescein (FAM) as the probe label. Briefly, total RNA was extracted from a $100 \mathrm{mg}$ portion of frozen perirenal fat tissue using the RNeasy Lipid Tissue Mini Kit (Qiagen), which is designed for use in fatty tissues. The quality and quantity of total RNA were determined via capillary electrophoresis using an Agilent 2100 Bioanalyzer (Agilent Technologies, Wilmington, DE, USA). Real-time RT-PCR reagents, probes and primers were purchased and used as recommended by Applied Biosystems. For each sample $\sim 54$ ng total RNA was subjected to RT in triplicate to generate first-strand cDNA using the TaqMan RT reagents and Multiscribe Reverse Transcriptase. Polymerisation and amplification reactions for each RT sample were carried out in duplicate in a final volume of $20 \mu \mathrm{l}$ using the Applied Biosystems 7500 Fast Real-Time PCR system. Quantification was performed using a relative standard curve method with serial dilutions of a reference standard cDNA generated from RNA pooled from the perirenal fat of 11-week-old lambs (3 $\mathrm{N}$ males and $3 \mathrm{~N}$ females). Individual mRNA levels of the genes of interest were expressed relative to the sample's own internal 18S RNA, determined using human 18S pre-developed TaqMan assay reagents from Applied Biosystems. The samples were randomised to ensure that each prenatal growth category and both genders were equally represented in each of four 96-well plates. In addition, a quality control sample generated from the above RNA pool was run on each plate and used to calculate the inter- and intra-assay coefficient of variation

Published by Bioscientifica Ltd. 
(CV) for each gene of interest. Intra-plate CV varied from 3.4 to $10.9 \%$ for individual genes (overall mean \pm s.e.M., $5.5 \pm 0.68 \%$ ), while inter-plate $\mathrm{CV}$ varied from 2.3 to $9.3 \%$ (overall mean \pm s.e.M., $5.0 \pm 0.76 \%$ ).

\section{Quantification of adipocyte size and number}

Typically $5 \times 8 \mu \mathrm{m}$ sections were cut from each individual animal at an approximate interval of $100 \mu \mathrm{m}$ to ensure that each section contained a unique sampling of adipocytes. The sections were stained with haematoxylin and eosin and viewed at $100 \times$ magnification under a Leica microscope. Ten separate representative fields of view per animal were captured using a digital camera and the images subsequently analysed using Image-Pro Plus, version 4.5.1 Software (Media Cybernetics, Inc., Silver Spring, MD, USA). After conversion to grayscale, 50 adjacent cells/image were manually tagged and traced in order to calculate the average adipocyte size (surface area). Within individual animals, all adipocytes were of a similar size (Fig. 1) and hence the total number of adipocytes per image was derived by dividing the total image area by the area of these 50 representative cells $(\times 50)$. The validity of this approach was confirmed by manually tagging all adipocytes in the standard field of view in 100 separate images, and a good correlation between both approaches was obtained $(r=0.954, P<0.001)$. The mean $\mathrm{CV}$ for the measurement of adipocyte cell size and number between images for individual animals was $<10 \%$.

\section{Statistical analysis}

Date are presented as the mean \pm s.E.M. and all statistical comparisons were made using Minitab (Minitab 16, Minitab, Inc., State College, PA, USA). All offspring data were analysed using the general linear model ANOVA to determine the effects of prenatal growth status and gender, and any interaction. Where appropriate, post hoc comparison between groups was made by Tukey's method. Pearson product-moment correlation analyses and linear regression were used to explore relationships between variables where indicated, and data are presented as correlation coefficients $(r)$. Statistical significance was taken as $P<0.05$.
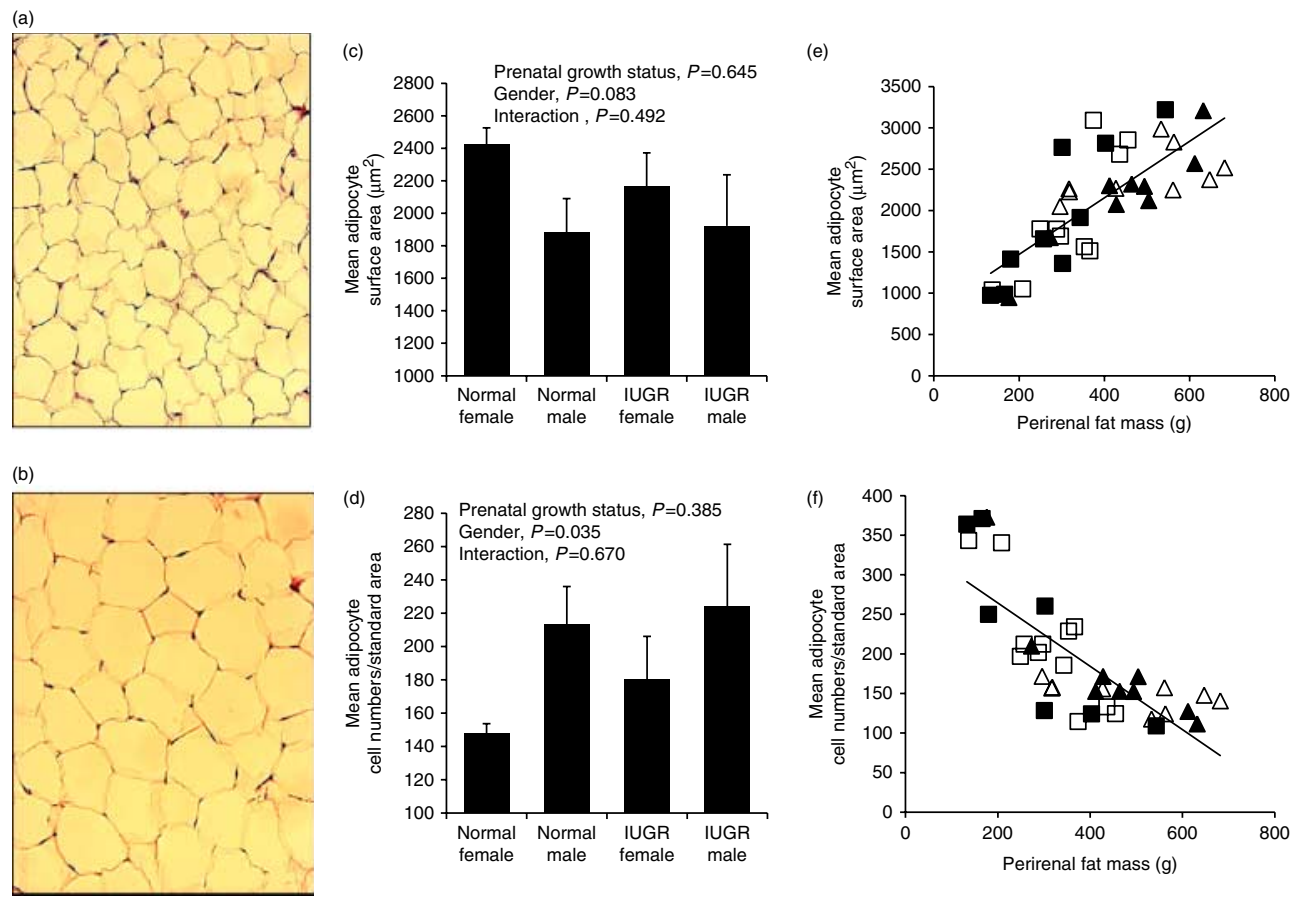

\section{Figure 1}

Haematoxylin and eosin-stained sections of perirenal fat from a representative (a) male lamb and (b) female lamb; adipocyte size (c) and number (d) by prenatal growth status and gender and relationships between perirenal fat mass and (e) adipocyte size $(r=0.774, n=37, P<0.001)$ and (f) number
(C) 2014 Society for Endocrinology Printed in Great Britain
( $r=0.772, P<0.001)$ in male (squares) and female (triangles) lambs at 11 weeks of age. Solid symbols denote lambs categorised as IUGR at birth and open symbols denote normal birth weight category. A full colour version of this figure is available at http://dx.doi.org/10.1530/JME-14-0123. 


\section{Results}

\section{Lamb growth and metabolic hormone concentrations}

Sequential changes in eight indices of growth and in peripheral insulin, IGF1 and leptin concentrations measured at 5-day intervals throughout an 11-week study period have been presented previously, together with the insulin response to glucose challenge and body composition at necropsy (Wallace et al. 2014). Selected data are reproduced herein (Table 1 ) in order to provide context for the new NEFA, glycerol, lipid and perirenal fat gene expression data.

Gestation length was independent of prenatal growth category, and all lambs were spontaneously delivered between 137 and 144 days gestation and as such were variously preterm (term $=145-147$ days). Relative to normal birth weight lambs, those categorised as IUGR lambs weighed less and had lower peripheral plasma insulin and IGF1 concentrations at birth. These birth parameters were independent of gender. Fractional growth velocity for body weight (\%/day; calculated by expressing the live weight gained between birth and necropsy as a proportion of lamb birth weight and dividing by the time interval between birth and necropsy) was higher in IUGR vs $\mathrm{N}$ groups and independent of gender. Nevertheless, IUGR lambs had lower absolute growth rates and remained lighter than $\mathrm{N}$ lambs at
11 weeks of age. Adiposity status, as indicated by both the perirenal fat mass and percentage fat in the carcass, was equivalent between groups and thereby independent of prenatal growth status. Moreover, the weight of the perirenal fat mass was positively related to the overall carcass fat percentage in both IUGR and $\mathrm{N}$ groups ( $r=0.885, n=17$ and $r=0.760, n=21, P<0.001$ respectively). Males were heavier than females at necropsy and had a lower perirenal fat mass per kilogram body weight and a lower percentage carcass fat. These effects of gender on body composition were associated with higher mean plasma IGF1 and insulin and lower leptin levels in males during the 10 days before necropsy and were independent of prenatal growth status.

\section{Peripheral triglyceride, NEFA, glycerol and cholesterol concentrations}

Peripheral triglyceride and NEFA concentrations following a $3 \mathrm{~h}$ fast at 48 days of age were influenced by both prenatal growth status (IUGR $>\mathrm{N}$, Table 2) and gender (males $>$ females), largely due to higher concentrations in IUGR males (post hoc, $P<0.05$ ). Similarly, fasting glycerol levels were significantly impacted by prenatal growth status (IUGR $>\mathrm{N}$ ) with a trend for the highest concentrations in IUGR males. In non-fasted blood samples collected at 67-77 days of age during the final 10 days

Table 1 Effect of prenatal growth status and gender on gestation length, birth weight, absolute and fractional weight change, adiposity and metabolic hormone status. Data from Wallace et al. (2014). Values are mean \pm s.E.M.

\begin{tabular}{|c|c|c|c|c|c|c|c|}
\hline & \multicolumn{4}{|c|}{ Prenatal growth status and gender } & \multicolumn{3}{|c|}{$P$ value } \\
\hline & $\begin{array}{l}\text { Normal female } \\
\qquad(n=9)\end{array}$ & $\begin{array}{l}\text { Normal male } \\
\quad(n=12)\end{array}$ & $\begin{array}{l}\text { IUGR female } \\
\quad(n=9)\end{array}$ & $\begin{array}{l}\text { IUGR male } \\
\qquad(n=8)\end{array}$ & $\begin{array}{l}\text { Growth } \\
\text { status }\end{array}$ & Gender & Interaction \\
\hline Gestation length (days) & $139.5 \pm 0.5$ & $140.7 \pm 0.5$ & $139.2 \pm 0.6$ & $140.1 \pm 0.4$ & 0.421 & 0.070 & 0.848 \\
\hline Birth weight (g) & $4603 \pm 134$ & $4955 \pm 186$ & $3131 \pm 221$ & $3402 \pm 167$ & $<0.001$ & 0.103 & 0.830 \\
\hline Plasma insulin at birth (ng/ml) & $0.84 \pm 0.20$ & $0.96 \pm 0.10$ & $0.64 \pm 0.10$ & $0.53 \pm 0.05$ & 0.019 & 0.976 & 0.378 \\
\hline Plasma IGF1 at birth (ng/ml) & $254 \pm 19$ & $216 \pm 15$ & $148 \pm 17$ & $175 \pm 26$ & 0.001 & 0.783 & 0.105 \\
\hline $\begin{array}{l}\text { Weight change (days 0-77, } \\
\text { kg/day) }\end{array}$ & $0.390 \pm 0.007$ & $0.422 \pm 0.014$ & $0.344 \pm 0.013$ & $0.368 \pm 0.019$ & $<0.001$ & 0.054 & 0.767 \\
\hline FGR for weight (\%/day) & $8.51 \pm 0.23$ & $8.56 \pm 0.35$ & $11.31 \pm 0.70$ & $10.83 \pm 0.22$ & $<0.001$ & 0.620 & 0.535 \\
\hline Live weight at necropsy (kg) & $33.4 \pm 0.5$ & $37.6 \pm 1.0$ & $29.5 \pm 1.2$ & $32.8 \pm 1.5$ & $<0.001$ & 0.002 & 0.650 \\
\hline Perirenal fat mass (g/kg EBW) & $18.1 \pm 1.6$ & $10.2 \pm 0.8$ & $17.7 \pm 1.8$ & $11.0 \pm 1.6$ & 0.655 & $<0.001$ & 0.755 \\
\hline Fat per carcass $(\%)^{a}$ & $24.2 \pm 1.1$ & $20.7 \pm 0.8$ & $24.3 \pm 1.2$ & $20.2 \pm 1.0$ & 0.839 & $<0.001$ & 0.759 \\
\hline Crude protein per carcass $(\%)^{a}$ & $17.6 \pm 0.5$ & $18.8 \pm 0.2$ & $17.9 \pm 0.5$ & $18.3 \pm 0.4$ & 0.865 & 0.070 & 0.391 \\
\hline \multicolumn{8}{|c|}{ Mean plasma hormones - final 10 days } \\
\hline Insulin (ng/ml) & $2.7 \pm 0.22$ & $3.5 \pm 0.37$ & $2.9 \pm 0.19$ & $3.9 \pm 0.41$ & 0.365 & 0.010 & 0.658 \\
\hline IGF1 (ng/ml) & $354 \pm 10 *$ & $523 \pm 35^{\dagger}$ & $382 \pm 28 *$ & $681 \pm 37^{\ddagger}$ & 0.005 & $<0.001$ & 0.046 \\
\hline Leptin (ng/ml) & $4.1 \pm 0.53$ & $1.4 \pm 0.30$ & $3.8 \pm 1.62$ & $1.6 \pm 0.54$ & 0.920 & $<0.001$ & 0.575 \\
\hline
\end{tabular}

IUGR, intrauterine growth restriction; FGR, fractional growth rate; EBW, empty body weight. Post hoc comparison was by Tukey's method, and within a row, values with different superscript symbols differ at $P<0.05$.

a Determined by chemical analysis of minced carcass.

http://jme.endocrinology-journals.org DOI: $10.1530 / J M E-14-0123$
(C) 2014 Society for Endocrinology Printed in Great Britain
Published by Bioscientifica Ltd 
Table 2 Plasma lipid, glycerol and non-esterified fatty acid (NEFA) concentrations after a $3 \mathrm{~h}$ fast at $48.5 \pm 0.3$ days of age and during the 10 days before necropsy in relation to prenatal growth status and gender. Values are mean \pm s.E.M.

\begin{tabular}{|c|c|c|c|c|c|c|c|}
\hline & \multicolumn{4}{|c|}{ Prenatal growth status and gender } & \multicolumn{3}{|c|}{$P$ value } \\
\hline & $\begin{array}{l}\text { Normal female } \\
\quad(n=9)\end{array}$ & $\begin{array}{c}\text { Normal male } \\
\quad(n=12)\end{array}$ & $\begin{array}{l}\text { IUGR female } \\
\qquad(n=9)\end{array}$ & $\begin{array}{l}\text { IUGR male } \\
\qquad(n=8)\end{array}$ & $\begin{array}{l}\text { Growth } \\
\text { status }\end{array}$ & Gender & Interaction \\
\hline \multicolumn{8}{|c|}{ Fasting concentrations at 48 days $^{a}$} \\
\hline Triglycerides $(\mathrm{mmol} / \mathrm{l})$ & $0.416 \pm 0.026^{*}$ & $0.560 \pm 0.043^{*}$ & $0.495 \pm 0.047 *$ & $0.806 \pm 0.093^{\dagger}$ & 0.005 & 0.000 & 0.134 \\
\hline NEFA $(\mathrm{mmol} / \mathrm{l})$ & $0.352 \pm 0.057 *$ & $0.383 \pm 0.029 *$ & $0.366 \pm 0.035^{*}$ & $0.655 \pm 0.103^{\dagger}$ & 0.024 & 0.012 & 0.041 \\
\hline Glycerol $(\mu \mathrm{mol} / \mathrm{l})$ & $128.6 \pm 13.2^{*}$ & $126.9 \pm 11.5^{*}$ & $142.6 \pm 15.6^{*}{ }^{\dagger}$ & $214.5 \pm 36.4^{\dagger}$ & 0.014 & 0.083 & 0.069 \\
\hline Cholesterol (mmol/l) & $3.360 \pm 0.416$ & $2.769 \pm 0.174$ & $3.181 \pm 0.297$ & $3.580 \pm 0.291$ & 0.292 & 0.748 & 0.103 \\
\hline $\mathrm{HDL}(\mathrm{mmol} / \mathrm{l})$ & $2.181 \pm 0.258$ & $1.817 \pm 0.110$ & $2.217 \pm 0.188$ & $2.197 \pm 0.153$ & 0.256 & 0.294 & 0.347 \\
\hline $\mathrm{LDL}(\mathrm{mmol} / \mathrm{l})$ & $1.036 \pm 0.165$ & $0.756 \pm 0.064$ & $0.956 \pm 0.144$ & $1.183 \pm 0.175$ & 0.206 & 0.842 & 0.068 \\
\hline \multicolumn{8}{|c|}{ Final 10 days before necropsy ${ }^{b}$} \\
\hline Triglycerides $(\mathrm{mmol} / \mathrm{l})$ & $0.404 \pm 0.042^{*}{ }^{\dagger}$ & $0.502 \pm 0.040^{*},+$ & $0.392 \pm 0.027 *$ & $0.576 \pm 0.040^{\dagger}$ & 0.489 & 0.003 & 0.344 \\
\hline NEFA $(\mathrm{mmol} / \mathrm{l})$ & $0.234 \pm 0.034$ & $0.244 \pm 0.017$ & $0.224 \pm 0.022$ & $0.337 \pm 0.050$ & 0.183 & 0.051 & 0.103 \\
\hline Glycerol $(\mu \mathrm{mol} / \mathrm{l})$ & $74.4 \pm 5.5^{*}$ & $74.6 \pm 4.1 *$ & $77.3 \pm 5.6 *$ & $101.1 \pm 6.6^{\dagger}$ & 0.010 & 0.034 & 0.036 \\
\hline Cholesterol (mmol/l) & $2.501 \pm 0.238$ & $2.258 \pm 0.165$ & $2.344 \pm 0.152$ & $2.762 \pm 0.254$ & 0.399 & 0.670 & 0.112 \\
\hline $\mathrm{HDL}(\mathrm{mmol} / \mathrm{l})$ & $1.544 \pm 0.149$ & $1.381 \pm 0.097$ & $1.531 \pm 0.098$ & $1.676 \pm 0.138$ & 0.252 & 0.939 & 0.212 \\
\hline $\mathrm{LDL}(\mathrm{mmol} / \mathrm{l})$ & $0.776 \pm 0.101$ & $0.620 \pm 0.070$ & $0.656 \pm 0.055$ & $0.895 \pm 0.108$ & 0.366 & 0.627 & 0.026 \\
\hline
\end{tabular}

Post hoc comparison was by Tukey's method, and within a row, values with different superscript symbols differ at $P<0.05$

${ }^{a}$ Average of three samples collected at $10 \mathrm{~min}$ intervals over $20 \mathrm{~min}$ after a 3-h fast.

${ }^{b}$ Average of three samples collected at 5-day intervals mid-morning during the final 10 days before necropsy at 11 weeks of age.

before necropsy, average glycerol concentrations were higher in IUGR males relative to the other three categories, and the greater triglyceride concentrations in males vs females was similarly predominant due to the difference between IUGR males vs IUGR females; non-fasted NEFA concentrations followed a similar trend with highest levels in IUGR males (Table 2). Irrespective of prenatal growth status and gender, there was a positive relationship between concentrations measured at both time points in the fasted and non-fasted state $(r=0.666, r=0.815$ and $r=0.693, n=38, P<0.001$, for triglycerides, NEFA and glycerol respectively). Total cholesterol, HDL and LDL levels were also positively associated at both time points $(r=0.660$ to 0.780 , all $P<0.001$ ). Although not significantly impacted by either prenatal growth status or gender, the pattern at both time points was for greater total cholesterol in IUGR males, relative to the other three categories. A significant interaction in pre-necropsy LDL revealed higher levels in normal vs IUGR females contrasting with lower levels in normal vs IUGR males (Table 2).

For the population as a whole, no relationship existed between fasting triglyceride, NEFA or glycerol concentrations and indices of growth and adiposity including birth weight, fractional growth rate to the point of sample collection on postnatal day 48 , absolute and relative perirenal fat mass and carcass fat $\%$ at necropsy $(P>0.1)$. In contrast, fasting total, HDL and LDL cholesterol levels modestly predicted absolute and perirenal fat mass ( $r=0.404$ to $0.477, P=0.012-0.002)$ but not carcass fat \%. The relationships between fasting plasma triglycerides, NEFA, glycerol and cholesterol concentrations and indices of growth and adiposity within prenatal growth and gender categories are further detailed in Supplementary Table 2, see section on supplementary data given at the end of this article.

\section{Adipocyte size and number}

Within individuals, all adipocytes were of a similar size (Fig. 1a and b). Prenatal growth status did not influence adipocyte size or number (Fig. 1c and d), but relative to males the females had less adipocytes per standardised 'field of view' $(P=0.035)$ due to the adipocytes being generally larger $(P=0.083)$. Furthermore, for the study population as a whole, the perirenal fat mass was positively associated with adipocyte size and negatively with adipocyte number $(P<0.001$, Fig. 1e and f). Similar positive relationships (all $P<0.001$ ) were evident between adipocyte size and relative perirenal fat mass $(r=0.703)$, carcass fat $\%(r=0.592)$ and plasma leptin before necropsy $(r=0.623)$, while adipocyte number was inversely related to these the three indices of adiposity $(r=-0.701, r=-0.620$ and $r=-0.643$ respectively).

\section{Gene expression in perirenal fat}

The relative mRNA expression of genes putatively involved in adipocyte proliferation, differentiation and

Published by Bioscientifica Ltd 
metabolic function is given by prenatal growth status and gender in Table 3. Prenatal growth status did not influence the mRNA expression of any of the ten genes examined in the perirenal fat, and PPARG and G3PDH expression were additionally also independent of gender. In contrast, $H S L$, IGF1, IGF2, IGF1R and IGF2R mRNA expression was higher in males than in females $(P=0.007-<0.001)$, while expression of $L P L, F A S N$ and leptin was lower in males vs females $(P=0.035-<0.001)$ in parallel with the profound gender effect on perirenal fat mass (males $<$ females, $P<0.001)$. No prenatal growth status $\times$ gender interactions were evident for any genes measured.

In both male and female lambs, there were positive gene expression relationships between PPARG and G3PDH ( $r=0.509, P=0.022$ and $r=0.684, P=0.002$ respectively), between G3PDH and LPL $(r=0.506, P=0.023$ and $r=0.780, \quad P<0.001)$ and between $L P L$ and $F A S N$ $(r=0.558, P=0.010$ and $r=0.621, P=0.006)$ and a negative relationship between IGF1R and leptin $(r=-0.551, P=0.012$ and $r=-0.584, P=0.011)$.

The relationships between perirenal fat gene expression and indices of birth size, growth and body composition have been explored within each prenatal growth status category and within each sex and for the overall study population: no relationships were detected separately within IUGR or normal birth weight categories. There were few gender-specific associations between these aforementioned parameters and the IGF system (data not shown), and the positive relationship between leptin gene expression and indices of adiposity has largely been reported previously (Wallace et al. 2014). Data pertaining to the other five genes are presented in Table 4. Common to both sexes were negative associations between perirenal fat G3PDH mRNA expression and absolute perirenal fat mass, weightspecific perirenal fat mass, carcass fat percentage and adipocyte size. In males only, G3PDH was also negatively related to plasma leptin concentrations. In females only, $P P A R G$ expression was negatively correlated with birth weight and adipocyte size, and positively related to FGR. When examined for each sex separately, none of the genes were related to plasma insulin or IGF1 concentrations during the final days before necropsy.

The relationships between perirenal fat gene expression and indices of size, growth and body composition for the overall study population are detailed in Table 5. Using this approach, all four IGF system genes quantified were negatively related to indices of adiposity, including absolute and relative perirenal fat mass, carcass fat percentage, adipocyte size and plasma leptin, and positively correlated with plasma IGF1 concentrations (Fig. 2). Of the remaining genes, $L P L$ and FASN expression were weakly negatively correlated with plasma IGF1 (Table 5). For the population as a whole, LPL abundance was inversely correlated with fasting and non-fasting triglyceride, NEFA and glycerol concentrations $(r=-0.321$ to $-0.489, P=0.049-0.002)$ and with fasting total, HDL and LDL cholesterol levels $(r=-0.368$ to -0.415 , $P=0.023-0.01$ ). $G 3 P D H$ was also negatively related to non-fasting cholesterol parameters in the 10 days before necropsy $(r=-0.453$ to $-0.511, P=0.004-0.001)$. None of the other adipose tissue genes were related to any of the lipid biomarkers measured.

Table 3 Relative mRNA expression of ten genes involved in adipocyte growth and metabolism in perirenal fat in relation to prenatal growth status and gender. Refer to Table 1 for weight-specific perirenal fat mass and carcass fat percentage and Fig. 1 for adipocyte size. Values are mean \pm s.E.M.

\begin{tabular}{|c|c|c|c|c|c|c|c|}
\hline & \multicolumn{4}{|c|}{ Prenatal growth status and gender } & \multicolumn{3}{|c|}{$P$ value } \\
\hline & $\begin{array}{l}\text { Normal female } \\
\qquad(n=9)\end{array}$ & $\begin{array}{l}\text { Normal male } \\
\quad(n=12)\end{array}$ & $\begin{array}{l}\text { IUGR female } \\
\qquad(n=9)\end{array}$ & $\begin{array}{l}\text { IUGR male } \\
\quad(n=8)\end{array}$ & $\begin{array}{l}\text { Growth } \\
\text { status }\end{array}$ & Gender & Interaction \\
\hline Perirenal fat (g) & $483 \pm 49.2$ & $308 \pm 26.7$ & $444 \pm 51.9$ & $296 \pm 51.8$ & 0.555 & 0.001 & 0.755 \\
\hline $18 \mathrm{~S}$ & $0.030 \pm 0.003$ & $0.028 \pm 0.001$ & $0.028 \pm 0.002$ & $0.028 \pm 0.001$ & 0.440 & 0.875 & 0.428 \\
\hline PPARG:18S & $12.84 \pm 0.721$ & $14.19 \pm 0.901$ & $13.96 \pm 1.324$ & $12.51 \pm 1.064$ & 0.779 & 0.960 & 0.167 \\
\hline G3PDH:18S & $20.76 \pm 1.823$ & $23.49 \pm 1.253$ & $22.99 \pm 2.110$ & $23.46 \pm 2.542$ & 0.551 & 0.386 & 0.539 \\
\hline Leptin:18S & $26.4 \pm 1.922$ & $15.94 \pm 1.312$ & $23.6 \pm 1.579$ & $18.23 \pm 3.058$ & 0.901 & $<0.001$ & 0.202 \\
\hline$L P L: 18 S$ & $5.16 \pm 0.471$ & $4.42 \pm 0.289$ & $5.27 \pm 0.497$ & $4.03 \pm 0.364$ & 0.736 & 0.021 & 0.550 \\
\hline FASN:18S & $25.52 \pm 5.188$ & $15.16 \pm 2.512$ & $19.38 \pm 3.653$ & $13.97 \pm 2.466$ & 0.315 & 0.035 & 0.495 \\
\hline$H S L: 18 S$ & $16.13 \pm 1.010$ & $19.26 \pm 0.921$ & $16.00 \pm 0.800$ & $18.53 \pm 1.170$ & 0.668 & 0.007 & 0.761 \\
\hline IGF1:18S & $12.99 \pm 1.538$ & $21.15 \pm 1.286$ & $12.52 \pm 0.982$ & $23.77 \pm 2.464$ & 0.504 & $<0.001$ & 0.338 \\
\hline IGF2:18S & $16.02 \pm 1.356$ & $22.51 \pm 1.320$ & $13.84 \pm 0.941$ & $21.18 \pm 2.545$ & 0.274 & $<0.001$ & 0.788 \\
\hline IGF1R:18S & $13.44 \pm 0.701$ & $18.30 \pm 1.070$ & $14.03 \pm 0.849$ & $19.98 \pm 2.616$ & 0.425 & $<0.001$ & 0.698 \\
\hline IGF2R:18S & $17.16 \pm 1.458$ & $20.51 \pm 1.126$ & $17.17 \pm 0.838$ & $23.18 \pm 1.689$ & 0.309 & $<0.001$ & 0.312 \\
\hline
\end{tabular}


Table 4 Relationships between perirenal fat gene expression and indices of size, growth, adiposity and metabolic hormone status in female and male offspring, irrespective of prenatal growth category. Values are based on Pearson correlation coefficients with significant values shown in bold

\begin{tabular}{|c|c|c|c|c|c|}
\hline & \multicolumn{5}{|c|}{ Gene expression: 185} \\
\hline & PPARG & $G 3 P D H$ & $L P L$ & FASN & $H S L$ \\
\hline \multicolumn{6}{|l|}{ Females $(n=18)$} \\
\hline Birth weight $(\mathrm{g})$ & $-0.478 *$ & -0.239 & -0.085 & 0.233 & 0.313 \\
\hline FGR for weight (\%/day) ${ }^{a}$ & 0.526 * & 0.241 & 0.226 & -0.067 & -0.217 \\
\hline Perirenal fat mass $(\mathrm{g})$ & -0.176 & $-0.506^{\star}$ & -0.347 & $-0.469 *$ & -0.013 \\
\hline Perirenal fat mass ( $\mathrm{g} / \mathrm{kg}$ EBW) & -0.114 & $-0.481 *$ & -0.418 & $-0.586 *$ & -0.116 \\
\hline Fat per carcass $(\%)$ & -0.179 & -0.449 & -0.428 & -0.268 & -0.036 \\
\hline Adipocyte size $\left(\mu \mathrm{m}^{2}\right)$ & $-0.554^{\star}$ & -0.550 * & -0.445 & -0.259 & 0.361 \\
\hline Adipocyte number (per field) & $0.654^{\dagger}$ & $0.617^{\dagger}$ & 0.462 & 0.302 & -0.173 \\
\hline \multicolumn{6}{|l|}{ Pre-necropsy ${ }^{\mathrm{b}}$} \\
\hline Insulin (ng/ml) & -0.084 & -0.318 & -0.343 & -0.203 & 0.082 \\
\hline IGF1 (ng/ml) & 0.175 & 0.057 & 0.052 & -0.119 & 0.003 \\
\hline Leptin (ng/ml) & -0.163 & -0.394 & -0.397 & -0.308 & 0.189 \\
\hline \multicolumn{6}{|l|}{ Males $(n=20)$} \\
\hline Birth weight $(g)$ & 0.382 & -0.161 & 0.119 & -0.055 & 0.433 \\
\hline FGR for weight (\%/day) $)^{a}$ & -0.352 & 0.105 & -0.230 & -0.073 & -0.301 \\
\hline Perirenal fat mass $(\mathrm{g})$ & 0.072 & $-0.503 *$ & -0.199 & 0.094 & 0.275 \\
\hline Perirenal fat mass ( $\mathrm{g} / \mathrm{kg}$ EBW) & 0.005 & $-0.489 *$ & -0.159 & 0.184 & 0.116 \\
\hline Fat per carcass $(\%)$ & -0.057 & $-0.516^{*}$ & -0.265 & -0.095 & 0.476 * \\
\hline Adipocyte size $\left(\mu \mathrm{m}^{2}\right)$ & 0.003 & $-0.456^{\star}$ & -0.095 & 0.130 & 0.124 \\
\hline Adipocyte number (per field) & -0.112 & 0.395 & 0.090 & -0.138 & -0.238 \\
\hline \multicolumn{6}{|l|}{ Pre-necropsy ${ }^{b}$} \\
\hline Insulin (ng/ml) & -0.047 & -0.101 & -0.134 & -0.140 & 0.040 \\
\hline IGF1 (ng/ml) & -0.135 & -0.032 & -0.231 & -0.166 & -0.004 \\
\hline Leptin $(\mathrm{ng} / \mathrm{ml})$ & -0.222 & $-0.512^{*}$ & -0.205 & 0.148 & 0.217 \\
\hline
\end{tabular}

${ }^{\star} P<0.05,{ }^{\dagger} P<0.01$.

${ }^{\mathrm{a} C}$ Calculated from birth to necropsy.

${ }^{\mathrm{b}}$ Average of three samples collected at 5-day intervals mid-morning during the final 10 days before necropsy at 11 weeks of age.

\section{Discussion}

This study has two main findings. First, it reveals for the first time in early postnatal life a major effect of gender on adipose tissue gene expression which reflects the already established sexual dimorphism in body composition and is independent of IUGR status. Second, we found that fasting lipid concentrations were elevated in IUGR males, which may be a presage for adverse metabolic health and obesity in later life.

\section{Prenatal growth, gender and perirenal fat gene expression}

The design of this study allowed us to examine the effect of birth weight category on lipid status and adipose tissue gene expression free from potential confounding differences in gestation length (because all groups were similarly preterm) and in maternal nutritional status (because all dams were overnourished throughout pregnancy and lactation). Furthermore, the use of assisted conception procedures ensured genetic homogeneity (all offspring were half siblings), and all lambs were gestated as singletons with no differences due to in utero competition for nutrients. Unquestionably, we found no effect of birth weight category but a profound effect of gender on the expression of eight genes variously involved in adipogenesis, lipogenesis and adipokine signalling. Thus females had higher abundance of LPL, FASN and leptin concentrations, while males had higher abundance of HSL and of the four IGF system genes in perirenal fat. These clear cut gender-specific differences in adipocyte gene expression matched the markedly greater visceral and carcass fat deposition in gonad-intact female compared with male offspring, and were in line with the histological differences in adipocyte size. Thus this highly controlled study suggests that sexual dimorphism in the expression of a range of genes involved in adipose tissue biology is evident in early postnatal life and is not significantly affected by variations in prenatal nutrient supply at this early life stage. There are few comparable studies by other groups that have examined the impact of both IUGR and gender

Published by Bioscientifica Ltd. 
Table 5 Relationships between perirenal fat gene expression and indices of size, growth, adiposity and metabolic hormone status in all 38 lambs irrespective of prenatal growth category and gender. Values are based on Pearson correlation coefficients with significant values shown in bold

\begin{tabular}{|c|c|c|c|c|c|c|c|c|c|c|}
\hline & \multicolumn{10}{|c|}{ Gene expression:18S } \\
\hline & PPARG & G3PDH & $L P L$ & FASN & $H S L$ & Leptin & IGF1 & IGF2 & IGF1R & $I G F 2 R$ \\
\hline Birth weight (g) & -0.008 & -0.153 & -0.085 & 0.017 & $0.441^{\dagger}$ & -0.204 & 0.167 & 0.278 & 0.064 & 0.076 \\
\hline FGR for weight (\%/day) & 0.130 & 0.177 & 0.061 & -0.059 & -0.230 & 0.077 & 0.013 & -0.202 & -0.000 & -0.012 \\
\hline Perirenal fat mass $(\mathrm{g})$ & -0.062 & $-0.498^{\ddagger}$ & -0.025 & -0.034 & -0.149 & $0.614^{\ddagger}$ & $-0.510^{\ddagger}$ & $-0.498^{\ddagger}$ & $-0.440^{\dagger}$ & $-0.500^{\ddagger}$ \\
\hline Perirenal fat mass ( $\mathrm{g} / \mathrm{kg}$ EBW) & -0.058 & $-0.452^{\dagger}$ & 0.027 & -0.007 & -0.306 & $0.713^{\ddagger}$ & $-0.621^{\ddagger}$ & $-0.601^{\ddagger}$ & $-0.515^{\ddagger}$ & $-0.568^{\ddagger}$ \\
\hline Fat per carcass $(\%)$ & -0.113 & $-0.479^{\dagger}$ & -0.087 & 0.020 & -0.074 & $0.419^{\dagger}$ & $-0.470^{\dagger}$ & $-0.439^{\dagger}$ & $-0.399 *$ & -0.396 * \\
\hline Protein per carcass (\%) & 0.205 & 0.326 * & -0.195 & -0.222 & 0.224 & -0.263 & 0.217 & $0.324 *$ & 0.218 & 0.087 \\
\hline Adipocyte size $\left(\mu \mathrm{m}^{2}\right)$ & -0.192 & $-0.495^{\dagger}$ & -0.095 & 0.039 & 0.038 & $0.526^{\ddagger}$ & $-0.363^{*}$ & $-0.408 *$ & $-0.414^{*}$ & $-0.423^{\dagger}$ \\
\hline Adipocyte number (per field) & 0.166 & $0.485^{\dagger}$ & 0.077 & -0.040 & -0.023 & $-0.511^{\dagger}$ & 0.369 * & $0.401 *$ & $0.427^{\dagger}$ & $0.422^{\dagger}$ \\
\hline \multicolumn{11}{|l|}{ Pre-necropsy } \\
\hline Insulin (ng/ml) & -0.042 & -0.084 & -0.311 & -0.260 & 0.225 & 0.026 & 0.224 & 0.150 & 0.014 & 0.026 \\
\hline IGF1 (ng/ml) & -0.015 & 0.104 & $-0.338^{*}$ & $-0.326 *$ & $0.323 *$ & -0.292 & $0.572^{\ddagger}$ & 0.349 * & 0.338 * & 0.381 * \\
\hline Leptin $(\mathrm{ng} / \mathrm{ml})$ & -0.155 & $-0.428^{\dagger}$ & -0.003 & 0.093 & -0.152 & $0.572^{\ddagger}$ & $-0.518^{\ddagger}$ & $-0.487^{\dagger}$ & $-0.420^{\dagger}$ & $-0.432^{\dagger}$ \\
\hline
\end{tabular}

${ }^{*} P<0.05,{ }^{\dagger} P<0.01$ and ${ }^{\ddagger} P<0.001$.

on perirenal adipose tissue gene expression at an equivalent life stage. At 3 weeks of age in males but not females, PPARG and leptin gene expression were reduced in IUGR lambs (generated largely by pre-mating carunclectomy) independent of any change in fat mass (Duffield et al. 2009). Similar to this study, females $(n=11)$ were fatter than males $(n=12)$, but unlike data herein this was not associated with gender-specific differences in fat gene expression. In a study of twins and singletons with a wide variation in birth weight $(n=18), P P A R G$ gene expression in perirenal fat tissue at 5 months postnatal was inversely related to birth weight when males and females were combined, and birth weight (but not PPARG expression) was a strong predictor of body fat percentage by dualenergy X-ray absorptiometry (Muhlhausler et al. 2008). A similar relationship between PPARG expression and birth weight was observed in this study, but was confined to females only. In both the aforementioned studies, $L P L$ was measured, but unperturbed by either birth weight or gender. In contrast, and similar to the data herein, female lambs at 4 months postnatal had higher $L P L$ gene expression (in perirenal and subcutaneous fat depots) and higher fat mass (omental and perirenal) than males, which was largely independent of variations in maternal nutrition during the periconception period (Rattanatray et al. 2010). Furthermore, the intramuscular fatty acid profile of suckling female lambs at $\sim 5$ weeks postnatal was associated with upregulated $L P L$ expression relative to males of equivalent weight, which the authors suggest predisposes females to increased adiposity (Dervishi et al. 2012). There are no reports on FASN expression in relation to IUGR or gender in lambs, but in studies of IUGR vs normal male rat offspring, generated by either maternal protein restriction (Guan et al. 2005) or global nutrient restriction (Desai et al. 2008), visceral fat FASN gene expression was increased in adult life in association with higher fat mass and hypertrophic adipocytes respectively. The higher FASN expression in the adipose tissue of females vs males in this study is similarly in line with increased fatty acid synthesis and hence greater adipocyte size, and higher visceral and carcass adiposity. Hsl gene expression was not influenced by IUGR in the rat study mentioned earlier (Desai et al. 2008) and similarly HSL expression in perirenal fat was unperturbed at 18 days postnatal in IUGR lambs generated by maternal exposure to hyperthermia (Chen et al. 2010). This study is the first report on adipose tissue $H S L$ gene expression in relation to offspring gender, and the higher expression in males compared with females is commensurate with steroid hormone activation of HSL leading to enhanced lipolysis (Mayes \& Watson 2004) albeit well in advance of the major increase in testosterone associated with the endocrine onset of puberty (see below).

In the current study, the expression of all four genes relating to the IGF system was robustly greater in the adipose tissue of males compared with females and mirrored the higher IGF1 concentrations measured in the peripheral circulation before necropsy. These effects were independent of birth weight category. $\mathrm{GH}$ is the main regulator of $I G F 1$ expression in adipose tissue as well as liver, and IGF1 mRNA level in adipose tissue is increased by exogenous GH (Brameld et al. 1996). Thus, the gender difference in $I G F$ gene expression measured in this study is likely to directly reflect greater pituitary GH secretion in

Published by Bioscientifica Ltd. 

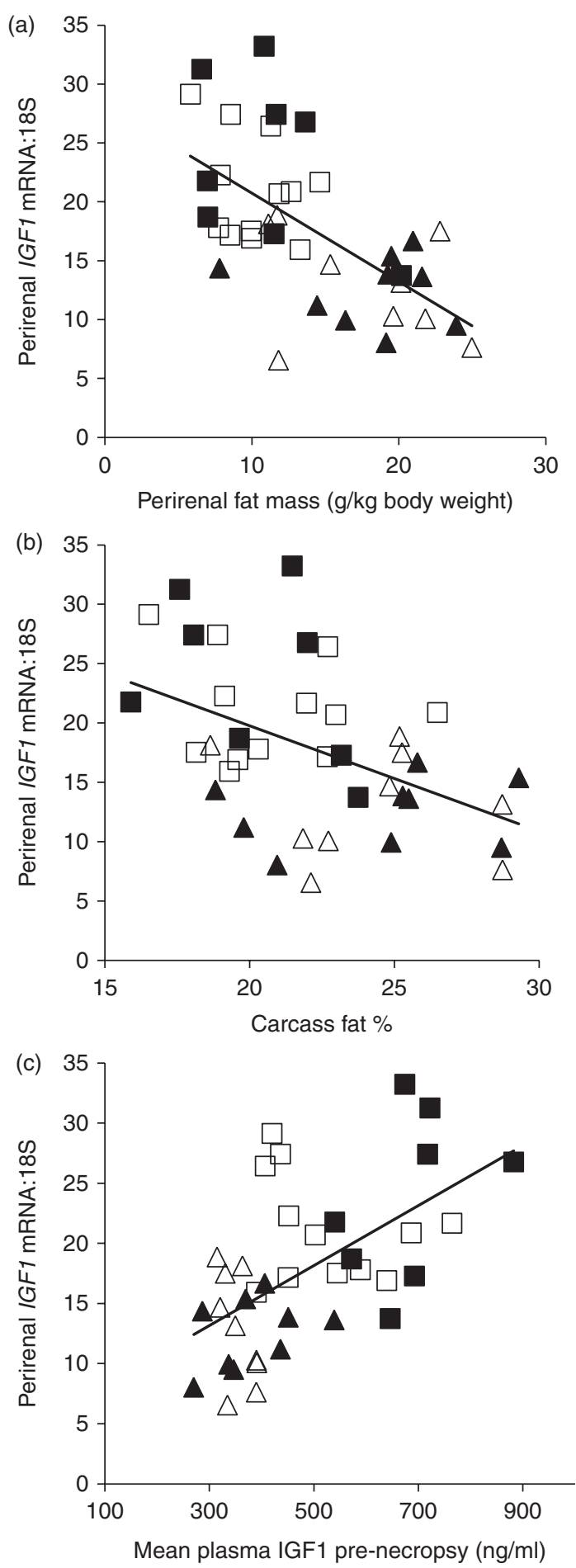

Figure 2

Relationships between perirenal IGF1 mRNA (relative to 18S) and (a) body weight-specific perirenal fat mass $(r=-0.621, P<0.001)$, (b) carcass fat percentage $(r=-0.470, P<0.01)$ and (c) mean plasma IGF1 concentrations in the final 10 days before necropsy $(r=0.572, P<0.001)$ in male (squares) and female (triangles) lambs at 11 weeks of age. Solid symbols denote lambs categorised as IUGR at birth and open symbols denote normal birth weight category. young growing male vs female offspring, as reported previously (Gatford et al. 1997). Although the liver is the main source of IGF, our data imply that adipose tissue may also contribute to peripheral IGF levels and as such may play a role in lean tissue growth and body composition. However, although we found consistent negative relationships between adipose tissue IGF system gene expression and all indices of adiposity measured, we did not detect any strong positive relationships with measures of lean tissue (only 1 weak positive association between adipose tissue IGF2 mRNA and the protein content of the carcass). The impact of IUGR and gender on adipose tissue expression of these IGF system genes in postnatal lambs has not been previously reported, but contrasting effects of maternal and foetal nutrient restriction have been documented prenatally, close to term. IGF1 mRNA level in perirenal fat was reduced in growth restricted foetuses (pre-mating carunclectomy model) independent of changes in body weight-specific perirenal fat mass (Duffield et al. 2008), while maternal nutrient restriction imposed during the period of rapid placental development was associated with higher IGF1R and IGF2R abundance and greater weight-specific perirenal fat mass (Bispham et al. 2003). Neither study reported foetal gender, but in light of the data presented in this study it is clearly an important consideration in such studies.

As detailed in the Introduction, the IGF system is integral to adipose tissue development with IGF1 and IGF2 having roles in adipocyte proliferation and differentiation (Holly et al. 2006, Kleiman et al. 2013), which in turn theoretically underlies a greater potential for enhanced fat mass. However, in the current early postnatal study, perirenal fat IGF ligand and receptor expression were inversely associated with adipocyte size, visceral fat mass and carcass fat content and positively associated with relative adipocyte number when these relationships were examined for the population as a whole. As yet, we have no information on the prenatal expression of these genes in this model, but the data herein are suggestive of marked temporal differences in adipose tissue development between sexes, with males on average being at an earlier stage of adipocyte maturity as inferred from the increased number of smaller adipocytes relative to the lower numbers of larger adipocytes in females during the early postnatal rearing period. The widespread sex-specific differences in adipose tissue gene expression observed in this study may reflect these gender differences in adipocyte development, but only in part, because the magnitude and high statistical significance of the group differences in gene expression contrast with the considerable variability

Published by Bioscientifica Ltd 
and overlap between groups with respect to adipocyte size/number (the latter being observable in Fig. 1). Irrespectively, while it is possible that greater IGFmediated effects on adipocyte proliferation and differentiation in early postnatal life in males may allow their adiposity to catch up with that of females at a later life stage, it is perhaps unlikely given what we know about the sexual dimorphism in body composition in large mammals throughout postnatal life (females fatter than males; McCarthy et al. 2006, Wells 2007). Irrespectively, the higher IGF1 and IGF2 gene expression and lower leptin mRNA in the visceral fat in male offspring, mirrored by lower circulating leptin, are commensurate with previously reported suppressive effects of these growth factors on leptin secretion both in vivo and in vitro (BöniSchnetzler et al. 1996, Bianda et al. 1997, Chen et al. 1998). The negative association between perirenal IGF1R and leptin mRNAs levels in both male and female offspring in the present study also agrees with such a role.

Overall our data for eight of the ten genes measured are suggestive of gender-dependent effects on adipose tissue gene expression and fat mass from early in the ovine life course. In partial support, foetal carcass fat percentage at day 81 of gestation is higher in females than in males (6.1 \pm 0.1 vs $5.6 \pm 0.1 \%, P<0.01, n=6 /$ group), while later in gestation perirenal fat mass is greater in normally growing females than in males (day 130; $5.6 \pm 0.3$ vs $3.7 \pm$ $0.4 \mathrm{~g} / \mathrm{kg}$ fetus, $P=0.001, n=24, \mathrm{~J}$ M Wallace, 2014, unpublished data). Similarly, a large population based cohort study has revealed that female infants are fatter than males when percentage body fat was measured within the first 4 days of life using air-displacement plethysmography (Hawkes et al. 2011). In addition to gender differences in pituitary GH secretion, which are most likely to come into play in postnatal life, differences in sex steroid secretion initially in prenatal life and extending forwards throughout the life course are likely to play a role in mediation of these gender-specific differences in body composition. Sheep and human gonads are steroidogenically active from the time of morphological sexual differentiation in early gestation (Winter et al. 1977, Quirke et al. 2001) and it is well established that postnatal adipose tissues from human, sheep and rodents possess oestrogen, progesterone and androgen receptors, and that sex steroid hormones can thereby influence adipose tissue biology by an array of complex genomic and non-genomic mechanisms (Mayes $\&$ Watson 2004). We have also recently reported genderspecific expression of anorexigenic and orexigenic energy balance genes in the arcuate nucleus of the hypothalamus in these lambs with no effect of IUGR (Adam et al. 2013). It is unknown whether these gender-specific effects on the regulatory genes involved in energy balance (Adam et al. 2013) and body composition (present study) persist into adult life or can be modified by manipulation of the postnatal environment.

In light of the above effects of gender on genes variously regulating adipocyte growth differentiation and metabolism, and our previously reported effects of both IUGR and gender on glucose metabolism in these lambs (Wallace et al. 2014), we were surprised that the expression of PPARG, the master adipocyte regulator, and G3PDH, encoding an enzyme linking lipogenesis and carbohydrate metabolism, were completely unperturbed. Nevertheless, in both male and female lambs, the expected positive relationship between PPARG and G3PDH and between $G 3 P D H$ and LPL mRNAs in the perirenal fat was observed. Furthermore, within both sexes, G3PDH mRNA expression was inversely associated with adipocyte size, visceral fat mass and carcass fat percentage. Intuitively, we may have expected a gene involved in fat storage to be positively related to these adiposity indices, but down regulation of gene expression for key lipogenic enzymes has been reported in the visceral fat of obese vs lean humans (Ortega et al. 2010).

\section{Prenatal growth and lipid status}

Triglyceride, NEFA and glycerol concentrations following a brief $3 \mathrm{~h}$ fast at 7 weeks of age were significantly elevated in male IUGR offspring relative to the other three groups, and a similar profile was observed in the non-fasted samples collected in the 10 days before necropsy. Likewise, there was a trend towards higher LDL cholesterol in both fasted and non-fasted samples in the male IUGR group. Similar relationships between low-birth weight and high peripheral lipid concentrations have been reported in early childhood and in later life in some (Barker et al. 1993, Roseboom et al. 2000, Soto et al. 2003) but not all (Byberg et al. 2000) human studies, and may additionally be related to the degree and speed of postnatal catch-up growth and to whether the infant received breast or formula milk (reviewed by Beltrand \& Levy-Marchal (2008)). In this study, there was no robust relationship between the measured lipid biomarkers and current growth or body composition as assessed, leading up to or at weaning (11 weeks of age), but nevertheless the observed dyslipidaemia in IUGR males may be a presage for subsequent adverse metabolic health and predisposition to obesity and cardiovascular disease in later life.

Published by Bioscientifica Ltd. 
Moreover the fact that the lipid disturbance was largely restricted to male rather than female IUGR offspring is in line with the generally greater male sensitivity to adverse prenatal insults programming aspects of renal function, hypertension and insulin resistance in a variety of rodent and ruminant models (reviewed by Aiken \& Ozanne (2013)). Although the increased NEFA and glycerol concentrations in IUGR males were not closely matched by increased adipose expression of the lipolytic HSL gene as might be expected, it is pertinent to note firstly that $H S L$ may be regulated at the enzyme activity level rather than at the mRNA level and secondly that other factors not measured in this study also contribute to lipolysis. Nonetheless, the higher peripheral NEFA and glycerol levels in IUGR groups are consistent with transiently enhanced fat mobilisation in line with the high energy demands of rapid postnatal compensatory growth that occurs once the low-birth weight lambs are released from the nutrient constraints of their prenatal environment. Clearly, long-term follow-up of a cohort of similarly growth perturbed lambs is required to resolve whether the currently observed dyslipidaemia persists beyond the rapid growth of the pre-weaning period and into adult life.

In conclusion, higher plasma lipids in IUGR males may predict later adverse metabolic health and obesity, but in early postnatal life, gender is the dominant influence on adipose tissue gene expression reflecting the already established sexual dimorphism in body composition. These data are consistent with both gender and prenatal growth, affording a major influence on adiposity and predisposition for obesity.

\section{Supplementary data}

This is linked to the online version of the paper at http://dx.doi.org/10.1530/ JME-14-0123.

\section{Declaration of interest}

The authors declare that there is no conflict of interest that could be perceived as prejudicing the impartiality of the research reported.

\section{Funding}

This study was funded by the Scottish Government's Rural and Environment Science and Analytical Services Division (RESAS), including the Strategic Partnership for Animal Science Excellence (SPASE).

\section{Acknowledgements}

The authors thank Graham Horgan (BioSS) for providing statistical advice.

\section{References}

Adam CL, Bake T, Findlay PA, Milne JS, Aitken RP \& Wallace JM 2013 Impact of birth weight and gender on early postnatal hypothalamic energy balance regulatory gene expression in the young lamb. International Journal of Developmental Neuroscience 31 608-615. (doi:10.1016/j.ijdevneu.2013.07.005)

Aiken C \& Ozanne SE 2013 Sex differences in developmental programming models. Reproduction 145 R1-R13. (doi:10.1530/REP-11-0489)

Barker DJ, Hales CN, Fall CH, Osmond C, Phipps K \& Clark PM 1993 Type 2 (non-insulin-dependent) diabetes mellitus, hypertension and hyperlipidaemia (syndrome X): relation to reduced fetal growth. Diabetologia 36 62-67. (doi:10.1007/BF00399095)

Beltrand J \& Levy-Marchal C 2008 Pathophysiology of insulin resistance in subjects born small for gestational age. Best Practice \& Research. Clinical Endocrinology \& Metabolism 22 503-515. (doi:10.1016/j.beem.2008.01.015)

Bianda T, Froesch ER \& Schmid C 1997 Growth hormone and serum leptin in GH-deficient adults. Clinical Endocrinology 47 502-503.

Bispham J, Gopalakrishnan GS, Dandrea J, Wilson V, Budge H, Keisler DH, Broughton Pipken F, Stephenson T \& Symonds ME 2003 Maternal endocrine adaptation throughout pregnancy to nutritional manipulation: consequences for maternal leptin and cortisol and programming of fetal adipose tissue development. Endocrinology $\mathbf{1 4 4}$ 3575-3585. (doi:10.1210/en.2003-0320)

Böni-Schnetzler M, Gosteli-Peter MA, Moritz W, Froesch ER \& Zapf J 1996 Reduced $o b$ mRNA in hypophysectomised rats is not restored by growth hormone (GH), but further suppressed by exogenously administered insulin-like growth factor 1 (IGF1). Biochemical and Biophysical Research Communications 225 296-301. (doi:10.1006/ bbrc.1996.1169)

Brameld JM, Atkinson JL, Saunders JC, Pell JM, Buttery PJ \& Gilmour RS 1996 Effects of growth hormone administration and dietary protein intake on insulin-like growth factor 1 and growth hormone receptor mRNA expression in porcine liver, skeletal muscle, and adipose tissue. Journal of Animal Science 74 1832-1841.

Bruce LA, Atkinson T, Hutchinson JSM, Shakespear RA \& MacRae JC 1991 The measurement of insulin-like growth factor I in sheep plasma. Journal of Endocrinology 128 R1-R4. (doi:10.1677/joe.0.128R001)

Byberg L, McKeigue PM, Zethelius B \& Lithell HO 2000 Birth weight and the insulin resistance syndrome: association of low birth weight with truncal obesity and raised plasminogen activator inhibitor-1 but not with abdominal obesity or plasma lipid disturbances. Diabetologia $\mathbf{4 3}$ 54-60. (doi:10.1007/s001250050007)

Chen XL, Hausman DB, Dean RG \& Hausman GJ 1998 Hormonal regulation of leptin mRNA expression and preadipocyte recruitment and differentiation in porcine primary cultures of S-V cells. Obesity Research 6 164-172. (doi:10.1002/j. 1550-8528.1998.tb00331.x)

Chen X, Fahy AL, Green AS, Anderson MJ, Rhoads RP \& Limesand SW 2010 $\beta_{2}$-Adrenergic receptor desensitization in perirenal adipose tissue in fetuses and lambs with placental insufficiency-induced intrauterine growth restriction. Journal of Physiology $\mathbf{5 8 8} 3539-3549$. (doi:10.1113/ jphysiol.2010.192310)

De Blasio MJ, Gatford KL, Robinson JS \& Owens JA 2007 Placental restriction of fetal growth reduces size at birth and alters postnatal growth, feeding activity, and adiposity in the young lamb. American Journal of Physiology. Regulatory, Integrative and Comparative Physiology 292 R875-R886. (doi:10.1152/ajpregu.00430.2006)

Dervishi E, Joy M, Alvarez-Rodriguez J, Serrano M \& Calvo JH 2012 The forage type (grazing versus hay pasture) fed to ewes and the lamb sex affect fatty acid profile and lipogenic gene expression in the longissimus muscle of suckling lambs. Journal of Animal Science 90 54-66. (doi:10.2527/jas.2011-4057)

Desai M, Han G, Ferelli M, Kallichandra N \& Lane RH 2008 Programmed upregulation of adipogenic transcription factors in intrauterine 
growth-restricted offspring. Reproductive Sciences 15 785-796. (doi:10.1177/1933719108318597)

Duffield JA, Vuocolo T, Tellam R, Yuen BS, Muhlhausler BS \& McMillen IC 2008 Placental restriction of fetal growth decreases IGF1 and leptin mRNA expression in the perirenal adipose tissue of late gestation fetal sheep. American Journal of Physiology. Regulatory, Integrative and Comparative Physiology 294 R1413-R1419. (doi:10.1152/ajpregu. 00787.2007)

Duffield JA, Vuocolo T, Tellam R, McFarlane JR, Kauter KG, Muhlhausler BS $\&$ McMillen IC 2009 Intrauterine growth restriction and the sex specific programming of leptin and peroxisome proliferatoractivated receptor- $\gamma$ (PPAR- $\gamma$ ) mRNA expression in visceral fat in the lamb. Pediatric Research 66 59-65. (doi:10.1203/PDR. Ob013e3181a7c121)

Gatford KL, Fletcher TP, Rao A, Egan AR, Hosking BJ \& Clarke IJ 1997 GH, GH-releasing factor and somatostatin in the growing lamb: sex differences and mechanisms for sex differences. Journal of Endocrinology 152 19-27. (doi:10.1677/joe.0.1520019)

Guan H, Arany E, van Beek JP, Chamson-Reig A, Thyssen S, Hill DJ \& Yang K 2005 Adipose tissue gene expression profiling reveals distinct molecular pathways that define visceral adiposity in offspring of maternal protein-restricted rats. American Journal of Physiology. Endocrinology and Metabolism 288 E663-E673. (doi:10.1152/ajpendo. 00461.2004)

Hawkes CP, Hourihane JO, Kenny LC, Irvine AD, Kiely M \& Murray DM 2011 Gender- and gestational age-specific body fat percentage at birth. Pediatrics 128 e645-e651. (doi:10.1542/peds.2010-3856)

Hokken-Koelega AC, De Ridder MA, Lemmen RJ, Den HH, De Muinck Keizer-Schrama SM \& Drop SL 1995 Children born small for gestational age: do they catch up? Pediatric Research 38 267-271. (doi:10.1203/ 00006450-199508000-00022)

Holly J, Sabin M, Perks C \& Shield J 2006 Adipogenesis and IGF-1. Metabolic Syndrome and Related Disorders 4 43-50. (doi:10.1089/met.2006.4.43)

Kleiman A, Keats EC, Chan NG \& Khan ZI 2013 Elevated IGF2 prevents leptin induction and terminal adipocyte differentiation in hemangioma stem cells. Experimental and Molecular Pathology 94 126-136. (doi:10.1016/j.yexmp.2012.09.023)

Long NM, Rule DC, Zhu MJ, Nathanielsz PW \& Ford SP 2012 Maternal obesity upregulates fatty acid and glucose transporters and increases expression of enzymes mediating fatty acid biosynthesis in fetal adipose tissue depots. Journal of Animal Science 90 2201-2210. (doi:10.2527/jas.2011-4343)

Louey S, Cock ML \& Harding R 2005 Long term consequences of low birthweight on postnatal growth, adiposity and brain weight at maturity in sheep. Journal of Reproduction and Development 51 59-68. (doi:10.1262/jrd.51.59)

MacRae JC, Bruce LA, Hovell D, Hart IC, Inkster J \& Atkinson T 1991 Influence of protein nutrition on the response of growing lambs to exogenous bovine growth hormone. Journal of Endocrinology 130 53-61. (doi:10.1677/joe.0.1300053)

Marie M, Findlay PA, Thomas L \& Adam CL 2001 Daily patterns of plasma leptin in sheep: effects of photoperiod and food intake. Journal of Endocrinology 170 277-286. (doi:10.1677/joe.0.1700277)

Matsuzaki M, Milne JS, Aitken RP \& Wallace JM 2006 Overnourishing pregnant adolescent ewes preserves perirenal fat deposition in their growth-restricted fetuses. Reproduction, Fertility, and Development 18 357-364. (doi:10.1071/RD05067)

Mayes JS \& Watson GH 2004 Direct effects of sex steroid hormones on adipose tissues and obesity. Obesity Reviews 5 197-216. (doi:10.1111/j. 1467-789X.2004.00152.x)

McCarthy HD, Cole TJ, Fry T, Jebb SA \& Prentice AM 2006 Body fat reference curves for children. International Journal of Obesity $\mathbf{3 0}$ 598-602. (doi:10.1038/sj.ijo.0803232)

Muhlhausler BS, Duffield JA \& McMillen IC 2007 Increased maternal nutrition stimulates peroxisome proliferator activated receptor- $\gamma$, adiponectin, and leptin messenger ribonucleic acid expression in

http://jme.endocrinology-journals.org DOI: 10.1530/JME-14-0123
() 2014 Society for Endocrinology Printed in Great Britain adipose tissue before birth. Endocrinology 148 878-885. (doi:10.1210/ en.2006-1115)

Muhlhausler BS, Ritorto V, Schultz C, Chatterton BE, Duffield JA \& McMillen IC 2008 Birth weight and gender determine expression of adipogenic, lipogenic and adipokine genes in perirenal adipose tissue in the young adult sheep. Domestic Animal Endocrinology 35 46-57. (doi:10.1016/j.domaniend.2008.01.007)

Nightingale CM, Rudnicka AR, Owen CG, Donin AS, Newton SL, Furness CA, Howard EL, Gillings RD, Wells JC, Cook DG et al. 2013 Are ethnic and gender specific equations needed to derive fat free mass from bioelectrical impedance in children of South Asian, black African-Caribbean and white European origin? Results of the assessment of body composition in children study PLOS ONE 8 e76426. (doi:10.1371/journal.pone.0076426)

Ojha S \& Budge H 2012 Early origins of obesity and development. In Adipose Tissue Biology, pp 379-408. Ed ME Symonds. Springer Science+ Business Media.

Ong KK, Ahmed ML, Emmett PM, Preece MA \& Dunger DB 2000 Association between postnatal catch-up growth and obesity in childhood: prospective cohort study. BMJ 320 967-971. (doi:10.1136/bmj. 320.7240.967)

Ortega FJ, Mayas D, Moreno-Navarrete JM, Catalán V, Gómez-Ambrosi J, Esteve E, Rodriguez-Hermosa JI, Ruiz B, Ricart W, Peral B et al. 2010 The gene expression of the main lipogenic enzymes is down regulated in visceral adipose tissue of obese subjects. Obesity 18 13-20. (doi:10.1038/ oby.2009.202)

Parsons TJ, Power C \& Manor O 2001 Fetal and early life growth and body mass index from birth to early adulthood in 1958 British cohort: longitudinal study. BMJ 323 1331-1335. (doi:10.1136/bmj.323. 7325.1331)

Quirke LD, Juengel JL, Tisdall DJ, Lun S, Heath DA \& McNatty KP 2001 Ontogeny of steroidogenesis in the fetal sheep gonad. Biology of Reproduction 65 216-228. (doi:10.1095/biolreprod65.1.216)

Rattanatray L, MacLaughlin SM, Kleeman DO, Walker SK, Muhlhausler BS \& McMillen IC 2010 Impact of maternal periconceptional overnutrition on fat mass and expression of adipogenic and lipogenic genes in visceral and subcutaneous fat depots in the postnatal lamb. Endocrinology 151 5195-5205. (doi:10.1210/en.2010-0501)

Roseboom TJ, van der Meulen JH, Osmond C, Barker DJ, Ravelli AC \& Bleker OP 2000 Plasma lipid profiles in adults after prenatal exposure to the Dutch famine. American Journal of Clinical Nutrition 75 1101-1106.

Scavo LM, Karas M, Murray M \& Leroith D 2004 Insulin-like growth factor-1 stimulates both cell growth and lipogenesis during differentiation of human mesenchymal stem cells into adipocytes. Journal of Clinical Endocrinology and Metabolism 89 3543-3553. (doi:10.1210/jc.2003-031682)

Semple RK, Chatterjee VK \& O'Rahilly S 2006 PPAR $\gamma$ and human metabolic disease. Journal of Clinical Investigation 116 581-590. (doi:10.1172/ JCI28003)

Soto N, Bazaes RA, Peña V, Salazar T, Avila A, Iñiguez G, Ong KK, Dunger DB \& Mericq MV 2003 Insulin sensitivity and secretion are related to catch-up growth in small-for-gestational-age infants at age 1 year: results from a prospective cohort. Journal of Clinical Endocrinology and Metabolism 88 3645-3650. (doi:10.1210/jc.2002-030031)

Wallace JM, Aitken RP, Milne JS \& Hay WW Jr 2004 Nutritionally-mediated placental growth restriction in the growing adolescent: consequences for the fetus. Biology of Reproduction 70 1055-1062. (doi:10.1095/ biolreprod.104.030965)

Wallace JM, Matsuzaki M, Milne J \& Aitken R 2006 Late but not early gestational growth hormone treatment increases fetal adiposity in overnourished adolescent sheep. Biology of Reproduction 75 231-239. (doi:10.1095/biolreprod.106.052605)

Wallace JM, Milne JS \& Aitken RP 2010 Effect of weight and adiposity at conception and wide variations in gestational dietary intake on pregnancy outcome and early postnatal performance in young 
adolescent sheep. Biology of Reproduction 82 320-330. (doi:10.1095/ biolreprod.109.080069)

Wallace JM, Aitken RP, Milne JS, Bake T \& Adam CL 2011 Growth, body composition and metabolism at neonatal and adolescent life stages in low birth weight offspring. Proceedings of the Nutrition Society 70 (OCE1, E7 (Abstract)). (doi:10.1017/ S0029665111000231)

Wallace JM, Aitken RP, Milne JS \& Adam CL 2014 Impact of embryo donor adiposity, birth weight and gender on early postnatal growth, glucose metabolism and body composition in the young lamb. Reproduction, Fertility, and Development 26 665-681. (doi:10.1071/RD13090)

Wells JCK 2007 Sexual dimorphism of body composition. Best Practice \& Research. Clinical Endocrinology \& Metabolism 21 415-430. (doi:10.1016/ j.beem.2007.04.007)

Winter JS, Faiman C \& Reyes FI 1977 Sex steroid production by the human fetus: its role in morphogenesis and control by gonadotropins. Birth Defects Original Article Series 13 41-58.

Received in final form 3 June 2014

Accepted 11 June 2014

Accepted Preprint published online 13 June 2014
Published by Bioscientifica Ltd. 